\title{
Some Letters from the Correspondence of Sir Herbert Taylor
}

THe following five letters, together with two others which are not thought to be of sufficient importance to be printed here, formed part of the large correspondence of General Sir Herbert Taylor (1775-1839), who was secretary to the duke of York, to George III, to Queen Charlotte, and to William IV. Sir Herbert Taylor left no son, and his large correspondence passed into the hands of his nephew, Mr. Herbert Edward Taylor, of Walmer, by whom these letters were presented to my mother just about fifty years ago. On my mother's death they became my property.

The recent publication of The Taylor Papers by Mr. Ernest Taylor, son of Mr. H. E. Taylor, recalled to my mind the existence of these letters, which I had almost forgotten. The originals have been presented to the Bodleian; but before presenting them I took careful copies of them. These copies I offered in the first instance to Mr. Ernest Taylor, in case he might care to use them for a volume supplementary to The Taylor Papers. He did not, however, see his way to use them in this manner, and they are now presented to the readers of the English Historical Review.

I am no specialist in the Napoleonic wars, and in the identification of some of the proper names I have had the help of my friend and colleague, Mr. R. B. Mowat, fellow of Corpus Christi College, Oxford.

C. Plummer.

\section{I}

Private.

Dublin Castle, Feby 22d, 1801.

Sir,

The time is now drawing near when I am to retire from the Government of this Island, and probably from all political situation and public life.

Much as I desired to be relieved from the office of Lieutenant of Ireland, I could have wished that the circumstances of my retreat had been more auspicious; but however erroneous my judgement may have been, I trust that His Majesty will believe that in recommending the measure of which $\mathrm{He}$ has so highly disapproved, ${ }^{1}$ I have been actuated by no other motive than a desire to strengthen his hands against his numerous enemies, to secure the loyalty of three millions of his subjects, and to put ${ }^{8}$ an end to the cruel horrors which have so long afflicted, and have latterly gone very near to overwhelm the country, which in the hour of extreme danger He was pleased to commit to my charge.

Your Royal Highness has been constantly informed of my opinions, and of all the steps which I have taken in the Military part of my duty,

1 Catholic Emancipation.

2 Here, at the foot of the first page, is the address: His Royal Fighness, the Duke of York. 
and as I shall soon have the honor of paying my respects to you in person, I shall not now enter into any details on that subject.

Of the General Officers, on whom I am sorry to acknowledge that the civil Government of the Country has principally depended, I must in justice report that they have been very observant of my commands, and have conducted themselves with great discretion and moderation, and have formed a striking contrast in the minds of the people to the conduct of those Magistrates to whose violence and prejudices they have so long been accustomed.

If it should be intended that the Military command on my departure should devolve on Lord Clanricarde, it will be necessary that Lieut: General Ralph Dundas should be removed from the staff; and I feel it incumbent upon me on this occesion to bear testimony to your Royal Highness, that the behaviour of that Officer during the time that $\mathrm{He}$ has served under my command, has merited my perfect approbation.

I am, Sir, with the most sincere regard, and perfect attachment, Your Royal Highness's

Most Faithful

and most Devoted Servant

CoRnwallis.

Endorsed : Dablin 22nd Feb. 1801

Marquis Cornwallis

\section{II}

Dear Taylor.

Horse Guards, February 23, 1807.

As I shall see you tomorrow, and as I am a good deal pressed for time this evening, I shall not enter into the very interesting points mentioned in your letter, except to say that $I$ have for some time expected that some insidious proposal for a general peace would be made by Buonaparte to us. I hope in God that Ministers will have firmness and energy to reject it in a manly and firm manner.

The Question about Turkey is a very delicate one indeed, and requires much consideration.

\section{Ever}

Yours Most Sincerely

Frederick.

Eindorsed: Horseguards 23d February 1807

The Duke of York

III

Dear Taylor,

Horse Guards, November 25, 1813.

One line to thank you for your letter, by which I am sorry to find that you are detained at Harwich for lack of a ship.

The intelligence you give me as brought over by the Dutch who are arrived from Holland especially by my old friend Mr. Replaer, bears very strongly the marks of fear, and it is to be hoped that those who are remained in the country are blest with better Nerves. 
However according to the Information received this morning from the Crown Prince's ${ }^{3}$ Head Quarters at Bremen, General Winsingerode is moving with one column through Friezeland into Holland, and had already passed Zwol, while General Bulow was marching with another from Minden upon Arnheim, and the Crown Prince was to follow with the major part of his Army, having reinforced Walmoden with the Swedes and some Prussians, with orders to act in concert with General Benigsen against Davoust.

Marshal St. Cyr has given up Dresden and surrendered himself with sixteen thousand men prisoners of war to General Klenau, and Prince Swartzenberg has carried by assault the newly erected works at Hochheim.

My accounts from Wrede are very satisfactory.

Pray send as often as you can, and believe me ever yours most sincerely

Freiderick.

Barclay will have joined you this morning, I thought it best to send him off to take the chance of joining you.

Pray when you get to Holland do not forget to buy for me some of the best Curaçoa, the best I believe is made in Amsterdam.

Endorsed: D. of York. Nov. 25. 1813.

\section{IV}

Horse Guards, November 26, 1813.

Dear Taylor,

Though I hardly think that this will reach you before you set sail from Harwich, yet I can not refrain from writing one line to thank you for your letter received this morning, by which $I$ find, what indeed $I$ have always imagined, that it will be impossible for you to land any of your stores 'at this season of the year' ${ }^{\prime 5}$ on the open sea upon the coast of Holland.

I suppose that you will find the Russians and Prussians already in possession of a part of the Country, as by the Mail of this day from Heligoland a part of Count Winsengerode's Corps had already taken possession of Frieseland, and General Bulow was in full march from Minden upon Arnheim, so that long before this probably all the French troops which were at Utrect and Grave will have made their retreat.

Now God bless you-let me hear from you as often as you can and with best wishes for your success, believe me ever,

Dear Taylor,

Yours most Sincerely,

Frederick.

I will not fail to execute your commission at Windsor tomorrow.

Endorsed : Duke of York - November 261813.

- The Crown Prince of Sweden.

+ November l1th, 1813.

- Interlined. 
Private and Confudential.

My dear General,

London, May 15, 1832.

I have received your letter; and I am much obliged and flattered by His Majesty communioating to me the answer from Lord Grey, which is so far favourable as it does not contain any reference to the Proposition to which the King had objected.

I considered my commission as at an end when His Majesty renewed His communications with Lord Grey; and I took my Leave of the King.

I am convinced that it will tend to His Majesty's ease and convenience, ${ }^{\circ}$ if all communication with me should cease from this moment. I know that such cessation of communication will enable me to serve the King much more effectually if any further Service from me should be required.

I give you this Hint Privately. I shall not mention to any body that I have heard from you.

\section{Ever yours most Sincerely}

Wellington.

Endorsed : From the Duke of Wellington May 1832.

- Here, at the foot of the first page, is the address: General Sir Herbert Taylor. 